\title{
5. 'P-aris': Note for an Unwritten Volume of Strindberg's Autobiography
}

It is frequently assumed that by the end of 1894 Strindberg had turned away from literature and entered upon the period of scientific and alchemical experiment that accompanied the early phases of his Inferno crisis, that period of intense self-scrutiny, experiment, mental and spiritual turmoil and, ultimately, self-renewal that led to his re-emergence as a writer with Inferno in 1897 and To Damascus in 1898. However, this notion needs to be treated with some circumspection. As is so often the case with Strindberg, it is a view that originates with, and is fostered by, the author himself. As he informed $L e$ Temps, in 14 January 1895: 'At the moment I am returning to science, which I have never completely forsaken; but I am now going to devote myself to it and nothing else', while fifteen months later he continued to maintain, this time in Le Gaulois of 4 April 1896: 'I am entirely devoted to chemistry and botany. That is quite enough for me. Literature no longer interests me in the slightest.' Yet it is doubtful if Strindberg's neglect of literature was in fact as absolute as he suggests here. While his interest was certainly subdued during most of 1895 , it is evident from his letters, especially those to Torsten Hedlund in Gothenburg during 1895-6, that he was all the time considering the exploitation of his experiences in terms of literature. As Sven Delblanc has suggested, the Inferno crisis needs to be seen 'as an active rather than a passive process: Strindberg does not undergo a process of reshaping, rather he chooses in a magnificent, half-unconscious act of will an outlook on life that is morally meaningful and aesthetically fruitful'.' The question, as Strindberg was again the first to point out, was to find an adequate form for the experiences to which he opened himself during these years, and there were to be many stages on the way to his re-entry into literature.

One of these is to be found in a page of notes, hitherto (1979) unnoticed, in carton fifteen of Nordiska Museets Strindbergsarkivalia in the Royal Library in Stockholm. On the reverse of a series of chemical formulae headed 'Camphère $\mathrm{C}_{20} \mathrm{H}_{16}$ ' $[\mathrm{SgNM} 15: 5,23]$, in which Strindberg confirms to his own satisfaction his old supposition 'that chlorine is a hydrogen peroxide', are a series of entries, with the general title 'P-aris', which may, for a number of 
reasons, be considered Strindberg's very first attempt to come to terms with the early stages of his Inferno experiences. The notes, written on a folio sheet of Strindberg's customary Lessebo bikupa paper (watermark 1893) can be quite precisely dated, both by the nature of the subject matter and by their handwriting, to the end of January 1895. Indeed, it is the handwriting that is most immediately striking. Strindberg's usually neat, clear calligraphy is replaced here by an untidy and in places hardly legible script that suggests it was written only with considerable difficulty. And while the text itself is not specific, a reference in the notes to 'the Hospital' (Hospitalet), as well as a comparison with other examples of Strindberg's handwriting from the first weeks of 1895, suggest that these notes originate from the time when he was undergoing treatment for psoriasis in the Hôpital de Saint-Louis - a period he eventually describes in chapter one of Inferno.

There is thus an overlap between the period covered by these notes and the text of Inferno, although the bulk of their preoccupations is weighted on the first months of Strindberg's stay in Paris, immediately after his arrival there from Austria in August 1894. These preoccupations are the familiar ones of his journalism during the second half of 1894 and the first month of 1895, but the notes indicate an attempt to précis the events of this period in an effort to organize his experiences and determine their underlying pattern. For this reason it seems reasonable to dismiss the idea that they were intended merely as a continuation of his experimental prose study 'Sensations détraquées', which Strindberg considered undertaking in a letter to his current French translator, Georges Loiseau, on 23 January that year: 'Un pressentiment d'un jour prochain paralyse mon interêt de continuer. C'est dommage parce que je finirais si joliment ici à Saint Louis, plein de sensations sublimes, et comme battu après mes tentatives infertiles d'assiéger la grande ville, de Versailles, des hauteurs du Panthéon, du Montmartre, etc.' $[\mathrm{X}, 376] .^{2}$ They envisage far too elaborate a synthesis and are, moreover, too realistic in intention to be a fourth section of what, in a letter to the painter Richard Bergh, he called this 'symbolist-détraqué compromise with the poetry of science and madness' [X, 278]. Instead they retrace an entire phase, the first stage of which is identified with 'Ver-sailles' (again with the curious but characteristic hyphen, as in the title, 'P-aris'), where he originally stayed at the home of his old friend of the 1870s, Leopold Littmansson, on his arrival in the city. (The son of the cantor in the Jewish community in Stockholm, Littmansson had been the addressee of the important sequence of thirty-five, often extremely long letters in which Strindberg had explored his state of mind and intellectual holdings between June and August 1894, and had lived in Versailles for more than a decade, since his marriage to a wealthy Frenchwoman.) The notes end with the last entry to which a specific date can be set - the reference to 'Forges-les-Bains', 
where Strindberg seems briefly to have considered resuming his life with his second wife, Frida Uhl, who was currently living with their daughter at one of her parents' houses in Austria. 'In Forges-les-Bains two hours from Paris one can rent a three-roomed house with kitchen, reasonably furnished, for 300 Francs a year' [X, 368], he wrote to Frida around the middle of January 1895. Between these two points, in a column of more or less elaborately plotted items, Strindberg covers many of the familiar landmarks of his writing on Paris both at this time and afterwards, in Inferno, Legends, and Crimes and Crimes.

One group of names, for example, envisages a cab ride from the station at St Lazare, taking in the fashionable boulevards, the Bois de Boulogne and the Trocadero, including the neighbourhood of Passy where Strindberg stayed in a flat in the rue de Ranelagh during September 1894, courtesy of the confidence trickster Willy Pedersen (alias Grétor, 1868-1923). A speculator in forged paintings, Grétor acted as the somewhat dubious impresario for the painting in which Strindberg was engaged at this time. ${ }^{3}$ The conception recalls similar urban journeys in Jacob Wrestles and Alone in which the landscape of the city is employed to structure the narrator's feelings and direct his associations.

A second cluster of locations includes the carp pond in the Luxembourg Gardens ('I love the Jardin de Luxembourg and its carps', Strindberg wrote to Frida, in November 1894 [X, 291; 2, 515]), the Panthéon, Cluny and Notre Dame, as well as a reference to 'De la croix', which does not indicate which picture, if any, Strindberg had in mind although in all probability he is thinking of Delacroix' mural of Jacob Wrestling with the Angel in the Church of Saint-Suplice, a painting to which he returned not only in the fragment Jacob Wrestles in 1898 but also in several other of his post-Inferno works.

The sequence concludes with a series of allusions to the 'Invasions Barbare' and 'the Normans' (Normandera), and to the polemical standpoint of his article 'Le Barbare à Paris', which was published in Gil Blas in September 1895, but probably written during December $1894 .{ }^{4}$ Similarly, he also notes the controversies surrounding his essay 'De l'infériorité de la femme', which was published in the January 1895 issue of the symbolist journal La Revue Blanche, along with the newly written 'À la zoologie de la femme', as part of his contribution to the contemporary debate in France on woman's place in society, an intervention that brought Strindberg at least as much local notoriety as the recent production of Creditors by Lugné-Poë at the Théatre de l'EEuvre in June 1894. Furthermore, two references to the banquets which occupied a part of his time during this period, in the company of (variously) the publishers Albert Langen and Georges Charpentier, Lugné-Poë, and the poet and journalist Catulle Mendès, provoke the socially diffident writer to ponder 'what one should say' about the problems of prostitution and infidelity, and to recall, under his penname 'Columba', one of his adversaries, Henry Fouquier, 
who had rebutted Strindberg's views on women in an article in L'Echo de Paris (15 January 1895). His nom de plume qualified Fouquier for that most detested of Strindbergian categories, 'men who write under a woman's name' (män som skrifva i quinnans namn).

The most significant entries, however, are those which refer to the second of the five Inferno psychoses identified by Gunnar Brandell in Strindbergs infernokris. ${ }^{5}$ For it is here, in the events of December-January 1894-5, and in Strindberg's comments on them, that it is possible to discern certain underlying motifs that will reappear in the later autobiographical fictions from Inferno onwards. References to the 'Café Napolitain', where he was in the habit of taking his 'ear of Dionysus' (Dionysiusöra), or absinthe, between six and seven most evenings [X, 314; 2, 519] and to the cabaret at the 'Chat Noir', occasion the comment 'Néant'. From his correspondence with Frida, the role of the former and absinthe during this period of his life is apparent: 'An absinthe at the Café Napolitain sets everything in motion,' he told her in November 1894 [X, 300; 2, 517]. Meanwhile, both in its guise as Rudolphe Salis's well-known Montmartre cabaret where Strindberg once toyed with the idea of putting on a version of his fairy-tale play The Keys of Heaven (1892) rewritten according to fin-de-siecle dramatic principles and as the projected night club that he contemplated founding in Paris with Littmansson as a partner, the Chat Noir figured prominently in his mind at this time. 'Littmansson has been to see me and we have a plan to found a Chat Noir or a Procope Strindberg; I shall paint the walls and put on The Keys of Heaven as a shadow-play; my guitar will be there [and] Littmansson will direct the music according to the latest mode', he informed Frida, on 4 November 1894, before going on to admit that this would undoubtedly lead to 'chronic alcoholism and all the rest of it' [X, 296; 2, 516]. For in one of the preliminary structures that Strindberg was exploring as a possible template on which to organize his experience at this time, the 'Chat Noir' represented an alternative to the family he could no longer maintain either financially or in terms of his own psychological well-being. Anticipating the opposition between love and knowledge which underlies Inferno the cabaret was also the antithesis of Strindberg's other contemporary project, his desire to enter a monastery either of his own founding [X, 133-5; 2, 482-4] or an already established one such as the Trappist Notre-Dame d'Igny to which Huysmans retreated in 1891 or the Benedictine monastery at Maredsous where Strindberg would himself eventually stay briefly, in 1898. The words 'Klostret' (the monastery), 'La Trappe', and the life of an 'Erémite' (hermit) indicate the hold this scheme had on him at this time while in his correspondence he would frequently oscillate between the attractions of the cabaret or tavern, on the one hand, and his distaste for the degrading life of a bachelor on the town, on the other. 'The cabaret saves me from suicide' [X, 296; 2, 516], he told Frida in 
the same letter where he exclaimed in disgust, 'What a miserable existence! I detest mankind, but I can't stand being alone - hence: bad company, alcohol, late nights, Chat Noir, despair and all the rest of it' [X, 293; 2, 515]. But not until Inferno and To Damascus and the scenes in which he depicts his disturbed absinthe hour and the particles of soot that fall into his glass would he be able to place these conflicts in context, and create out of such apparent triviality the matter of his later art.

The same applies to the single comment 'Honour' (̈̈ran), which accompanies a reference to 'Père', or The Father, with which Lugné-Poë had followed up his recent production of Creditors at the Théâtre de l'CEuvre. (The Father opened on 13 December 1894.) The associations of honour in Strindberg's mind with pride, hubris and his choice of vocation, which again permeates the letters of this period, continues throughout the correspondence with Torsten Hedlund in 1896 and eventually finds its fully worked-out form in Inferno, To Damascus and Crimes and Crimes. The dramatist Maurice in the latter, for example, is exposed to the temptations of success and the nemesis divina that follows upon its appearance in the writer's life while the narrator of Inferno is confronted by the need to resolve the conflict between his vaunting desire for knowledge and power and the damage this inflicts on the life he might otherwise share with his wife and child.

But the climax of these notes, and what seems here to have been envisaged as the dramatic focus of any literary recuperation of his early Paris experience, is played down in his later writing. In these notes, however, a shaking hand produces

Hotellet. Den eviga elden. Vagname. Skakningen. Väck den [?]. Berättar Wedekind. Hamsun. Grétors besök. Det är visst julafton? Golfvet gungar; bordet skakar. Jag söker den fasta punkten! Hos andra! går ut.

[The hotel. The eternal fire. The waggons. Shaking. Wake it [?]. Tell Wedekind. Hamsun. Grétor's visit. It is surely Christmas Eve? The floor rocks; the table shakes. I am seeking the fixed point! With others! go out.]

In this instance, the straightforward list of names and subjects that characterizes the remainder of these notes is invigorated by the instantly dramatic present tense, as he recalls one of the most alarming of his many disturbing experiences during this period. A moment is relived intensely, namely the Christmas Eve that Strindberg spent in his lodgings at 14 rue de l'Abbé de l'Epée in 1894. Although he passes over these events in haste in Inferno, here they clearly stimulate ideas of 'Den eviga elden' (the eternal fire), and of a tottering world about to fall. For although he would subsequently toy with the idea that this attempt on his life was a surrogate for the suicide he had so often contemplated [X, 338], this note may be linked with a letter to Littmansson, written the 
day after the events mentioned here, in which Strindberg informs his friend that 'there was a devil here who wanted to murder me - so the innkeeper and I had to barricade the door when the murderer tried to force it' [X, 338]. And this assault was evidently associated in Strindberg's mind with Grétor and his circle, which included the emerging German dramatist, Frank Wedekind, and the Norwegian novelist, Knut Hamsun. ${ }^{6}$

Ever since Martin Lamm's early treatment of the status of these events in Strindberg's life, ${ }^{7}$ it has been customary to interpret this scene as just another unjustifiable outbreak of Strindberg's persecution mania. But since Sverker Hallén's ingenious close reading of the French text of the prose meditation 'In the Cemetery', in which he demonstrated how Strindberg had incorporated a passage into the original version of this essay published in Revue des Revues (15 July 1896), which reads on one level as an exercise in experimental symbolism based on free verbal association, and on another as a cipher of allusions intended for private consumption by Grétor and his circle, by whom Strindberg felt threatened, this is no longer possible. ${ }^{8}$ That there was substance in Strindberg's fears is now apparent. Whatever the precise nature of his insights into the underside of Grétor's activities as a trafficker in forged paintings or into the life (so finely dramatized by Wedekind some six years later in his play Der Marquis von Keith) that Grétor also forged for himself, Strindberg had reason to be alarmed at the power which Grétor might have over him from the time when he had stayed in Passy, in the house of Grétor's mistress, Rosa Pfaeffinger, and painted for him on commission. He thus sought to defend himself and in 'P-aris' he appears to have been considering relating what he knew quite openly. That he eventually settled for the allusive ingenuity of 'In the Cemetery' was probably more prudent, but in any event it is obvious that his relationship with Grétor and his contacts, although omitted from Inferno, played a role not greatly inferior to that of the Ferkel circle in stimulating his anxieties and shaping the course of his sometimes paranoid feelings during this period. If this is so then, for example, Strindberg's violent reaction to Knut Hamsun and the role which the latter played in collecting money among the Scandinavian community in Paris to alleviate Strindberg's destitution becomes more comprehensible, since Hamsun (as the note makes clear) was associated in Strindberg's mind with Grétor.

The question obviously arises why Strindberg never carried out this projected narrative. In part, as he wrote to Frida, it was because he had no one to write for, nobody who seemed willing to receive his more serious forms of expression: 'Write? But I have written so much. Paint, yet I have painted so much. The tavern [cabaret], Chat Noir, etc., clowning? No, I abhor the tavern, and yet am condemned to it!' [X, 298; 2, 516]. He was a writer without a public, a dramatist without a stage, the plays he had written before leaving Sweden 
in 1892 still unperformed there and the theatres of Paris now turning away from works by Scandinavian writers or contemplating a repertoire exclusively Ibsenite. And, as he asked Lugné-Poë, in December 1894: 'why must I [always] serve as Ibsen's gun-dog?' [X, 332; 2, 522].
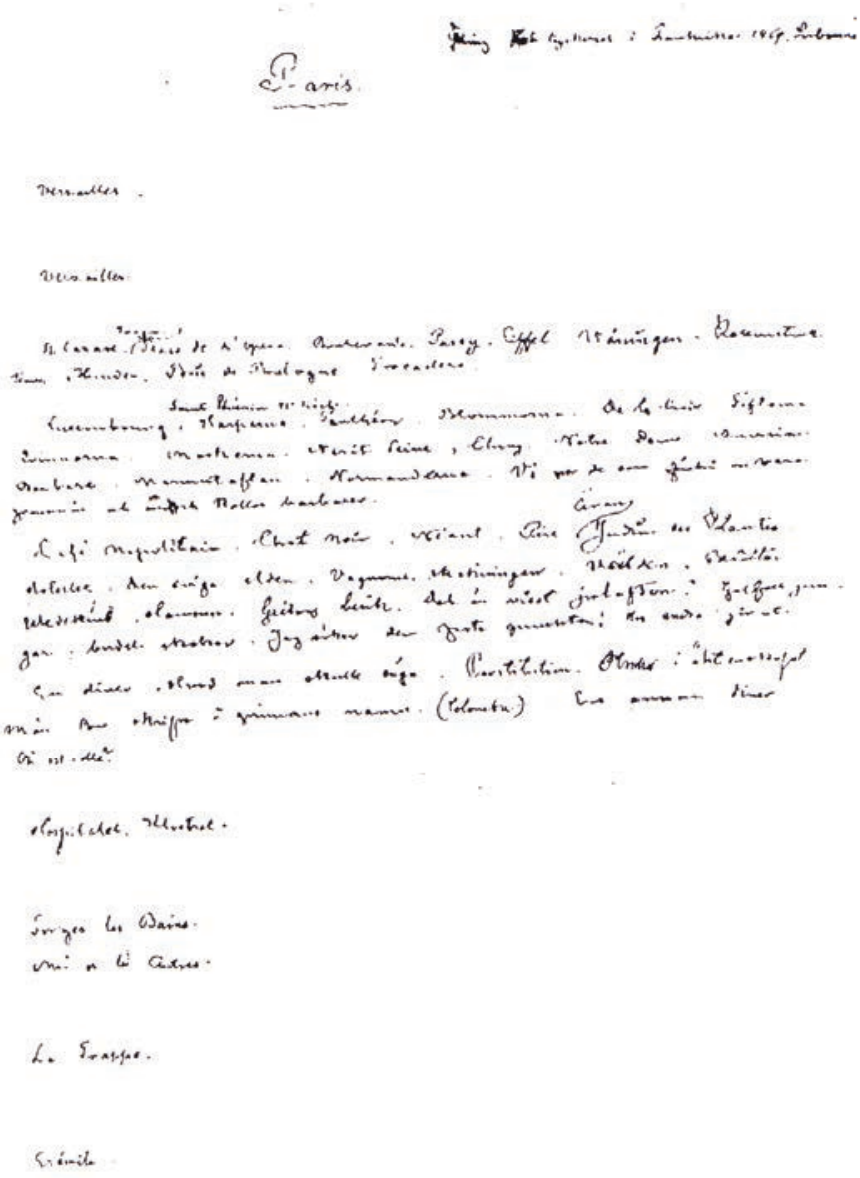

Reproduction of 'P-aris' [SgNM15 5,23] 
But the project was also no longer the type of literature he wished to write, at least in the straightforward transpository form of writing up his experience that these notes suggest. Since the furore created by his autobiographical fiction A Madman's Defence which had been published in France, pirated in Sweden and taken to court in Germany, he had been seeking an escape from the too naked exposure of naturalist writing $\grave{a}$ clef, that is, a prose narrative in which he transposed his shared experience directly into a literary narrative that appeared to countenance the reproduction of that experience with an immediacy rarely concealed behind only the most token camouflage. Hence 'I abandoned literature in order to escape being superficial' [XI, 138; 2, 547], he informed Torsten Hedlund, in March 1896, while in his reconstruction of this period in 1898, in The Cloister, his narrator recalls his writing 'the merciless portrayal of his first marriage' and recoils in the face of an occupation which lets the writer 'sit and fly [his] fellow human beings and then offer their skins for sale and expect them to buy them... To go about spying out people's secrets, to betray one's best friend's birthmark, use one's wife as a guinea pig, behave like a Croat, chop down, defile, burn and sell' [SV 50, 95]. He sought instead a manner of writing that was not so transparent and no longer 'superficial', where, in the terms he used of his paintings at this time, the esoteric meaning would supersede the exoteric $[\mathrm{X}, 178 ; 2,494]$. But this remained the achievement of later years. These notes suggest that 'P-aris' was all too obviously another series of episodes destined to be recaptured à clef. Before he could return to literature with an easy conscience he had first, as he writes here, to find 'den fasta punkten' outside himself, just as Axel Borg had remarked in By the Open Sea, Strindberg's novel from 1890: 'Give me a few more hypotheses, above all the fixed point outside myself, for I am quite adrift' [SV 31, 179]. Only when 'God, the fixed point outside us, by which alone we can accomplish anything' [XI, 284; 2, 585] was reestablished in his mind was Strindberg able to integrate the disparate parts of the Inferno experience in a formal narrative structure that would do them justice. 